\title{
Standard Operating Procedure Preservasi \\ Koleksi di Perpustakaan \\ (Studi Kasus di Perpustakaan Universitas Sarjanawiyata Tamansiswa Yogyakarta)
}

\author{
Batriatul Alfa Dila \\ *batriatul12z@gmail.com
}

\begin{abstract}
Implementation of information retrieval activities in a library is inseparable from the work role of the librarian, for that in a library there needs to be a written policy regarding standard operating procedures for preservation of collections in the library. This research traced information based on standard library procedures regarding collection development policies based on legal standards or preservation SOP policies, with qualitative research methods with the Snowball Sampling technique. The results of this study indicate that in the UST library has not implemented standard operating procedures in preservation collection activities, this is reflected in the process of preservation activities do not have a preservation SOP that is based on the legal basis for preservation of the collection as stated in the SOP document control contained in SOP No. 001.002 / ot 0101 / isn 6, Law Number 13 of 2018 concerning transfer of printed and recorded works, Regulation of the Head of the National Library Number 16 of 2014 concerning procedures for storing and using special collections and SNI 7330: 2009 for Higher Education libraries.
\end{abstract}

Keywords: Information search, collection preservation, Standard operating procedure 


\begin{abstract}
Abstrak
Pelaksanaan kegiatan penelusuran informasi di sebuah perpustakaan tidak terlepas dari peran kerja pada pustakawan, untuk itu didalam sebuah perpustakaan perlu adanya sebuah kebijakan tertulis mengenai standard operating procedure untuk preservasi koleksi di perpustakaan. Penelitian ini melakukan penelusuran informasi berdasarkan standar prosedur perpustakaan mengenai kebijakan pengembangan koleksi berdasarkan standar hukum atau kebijakan SOP preservasi, dengan metode penelitian kualitatif dengan teknik Snowball Sampling. Hasil dari penelitian ini menunjukan bahwa di perpustakaan UST belum melaksanakan standard operating procedure dalam kegiatan preservasi koleksi, hal ini tercermin dalam proses kegiatan preservasi belum mempunyai SOP preservasi yang berpijakan dengan landasan hukum pada preservasi koleksi yang tertuang pada SOP pengendalian dokumen yang tertuang pada No SOP 001.002/ot 01 01/isn 6, Undang-Undang Nomor 13 tahun 2018 tentang serah simpan karya cetak dan karya rekam, Peraturan Kepala Perpustakaan Nasional Nomor 16 Tahun 2014 tentang tata cara penyimpanan dan penggunaan koleksi khusus serta SNI 7330:2009 perpustakaan Perguruan Tinggi
\end{abstract}

Kata kunci : information search, collection preservation, standard operating procedure

\title{
Pendahuluan
}

Salah satu jenis perpustakaan ialah perpustakaan perguruan tinggi, perpustakaan perguruan tinggi disebut juga sebagai jantungnya universitas, karena tanpa adanya perpustakaan proses kegiatan belajar mengajar di lingkungan civitas akademika akan terganggu. Perpustakaan perguruan tinggi didirikan untuk menunjang pencapaian tujuan perguruan tinggi yang bersangkutan dalam melaksanakan Tri Darma Perguruan tinggi, yaitu pendidikan dan pengajaran, penelitian, dan pengabdian kepada masyarakat, Dalam melaksanakan kegiatan ini perpustakaan perguruan tinggi memilih, mengolah, mengkoleksi, merawat dan melayankan koleksi yang dimilikinya kepada lembaga induknya pada khususnya dan masyarakat akademis pada khususnya.(Rahayu Ningsih 2007)

Koleksi suatu perguruan tinggi tidak hanya terbatas dari jumlah dan jenis koleksi teks yang diperlukan sebagai penunjang kegiatan belajarmengajar tetapi juga buku-buku dan jurnal-jurnal ilmiah yang diperlukan 
untuk menunjang

penelitian para dosen dan mahasiswa, namun disamping itu juga perpustakaan perguruan tinggi juga mempunyai beberapa fungsi seperti fungsi edukasi, fungsi informasi, fungsi riset, fungsi rekreasi dan fungsi deposit. (Wijayanti Luki 2004) Salah satu komponen perpustakaan ialah koleksi.

Tanpa adanya koleksi yang baik dan memadai maka perpustakaan tidak akan memberikan layanan yang baik kepada penggunanya. Mengenai hal ini yang dimaksud dengan koleksi perpustakaan adalah semua bahan pustaka yang di kumpulkan, diolah, dam disimpan untuk disebarluaskan kepada masyarakat pengguna untuk memenuhi kebutuhan informasi mereka. Adapun tujuan pengadaan koleksi perpustakaan adalah untuk menunjang pelaksanaan program pendidikan, pengajaran, penelitian dan pengabdian kepada masyarakat.(Yuyu Yulia 2009)

Perpustakaan perguruan tinggi bersama-sama unit kerja lainnya mempunyai peran yang berbeda-beda, dengan tugas membantu perguruan tingginya dalam melaksanakan program Tri Darma Perguruan Tinggi masing-masing yang menanunginya. Perpustakaan perguruan tinggi sepenuhnya dikelola oleh perguruan tinggi tersebut sebagai lembaga induknya. Tujuan terlaksananya program kegiatan Tri Darma Perguruan Tinggi ialah untuk menunjang terlaksananya program kegiatan pendidikan, penelitian, pengabdian kepada masyarakat, melalui pelayan informasi yang meliputi aspek kegiatan pengumpulan informasi, pengelolaan perpustakaan, pemanfaatan koleksi, menyebarluakan informasi dan pemelihataan atau pelestarian koleksi.(Abdul Rahman Saleh 1995)

Pelestarian koleksi merupakan faktor yang penting dalam keberlangsungan sebuah perpustakaan, salah satu masalah utama yang dihadapi oleh perpustakaan ialah laju kerusakan koleksi yang jauh lebih cepat dibandingkan dengan pemeliharaan, perawatan dan perbaikannya.

Hal ini disebabkan oleh bahan yang umum dijadikan koleksi itu terbuat dari kertas dan plastik. Bahan tersebut terbuat dari bahan kertas berupa buku dan lembaran, yaitu monograf, surat kabar, terbitan berkala, naskah, 
peta, lukisan di atas kertas, leaflet, brosur, serta koleksi multimedia seperti pita suara, CD-ROM, dan piringan hitam. (Hartono 2015)

Koleksi bahan perpustakaan memiliki resiko kerusakan, baik dari dalam maupun dari luar bahan pustaka itu sendiri (seperti lingkungan dan kerusakan kerena ulah manusia). Setiap bahan perpustakaan mempunyai skala kerusakan yang berbeda-beda, namun pada umumnya semua jenis bahan perpustakaan yang mengalami kerusakan itu perlu penanganan lebih khusus untuk merawatnya yaitu dengan cara adanya kebijakan preservasi yang dimulai dari perencanaan yang baik berdasarkan kebijakan dengan memperhitungkan nilai, kegunaan dan resiko kerusakannya, dengan tujuan utama untuk melestarikan bahan perpustakaan, baik bentuk fisik dengan mempertahankan bentuk asli maupun isinya (informasi) yang terkadung melalui alih media dalam bentuk mikro ataupun transformasi digital. (Hartono 2015)

Semua kegiatan yang dilaksanakan di perpustakaan tidak terlepas dari penekanan standar pada setiap unit kerjanya. Hal ini memunculkan sebuah gagasan apakah perpustakaan sudah bekerja sesuai dengan prosedur standar yang berlaku dan pedoman yang sudah ditetapkan oleh perpustakaan. Gagasan tersebut dimaksudkan untuk mengendalikan kegiatan di perpustakaan agar sesuai dengan prosedur yang berlaku yaitu ketetapan Standard operating procedure (SOP) sebagai suatu aturan yang seharusnya dilakukan, prosedur merupakan serangkaian beberapa acuan kerja untuk mencapai suatu tujuan yang diterapkan pekerjaan yang terjadi secara berulang-ulang.(Endang Fatmawati, 2010)

Perpustakaan Universitas Sarjanawiyata Tamansiswa Yogyakarta mempunyai masalah pada proses kegiatan pelestarian dokumen khususnya pada kegiatan preservasi koleksi. Contohnya pada proses kegiatan pemeliharaan koleksi rusak yang masih belum terealisasi sesuai dengan tata aturan prosedur pelaksanaan preservasi yang sesuai dengan konteks kaidah ilmu perpustakaan, pada pelaksanaan kegiatan preservasi pustakawan di Perpustakaan Universitas 
Sarjanawiyata Tamansiswa Yogyakarta belum mempunyai pedoman SOP preservasi. Hal ini disebabkan bahwa perpustakaan Universitas Sarjanawiyata Tamansiswa Yogyakarta belum mempunyai kebijakan khusus mengenai Standard Operating Procedure (SOP) yang baku sebagai alat untuk menjadi panutan dalam pelaksanaan kegiatan presevasi koleksi.

Dalam penyusunan SOP perlu adanya sebuah perlindungan hukum seperti adanya sebuah peraturan perundang-undangan tertulis bahkan resmi mengenai pembuatan SOP sebagaimana yang tertulis pada SNI 7330:2009 tentang perpustakaan yang menyatakan bahwa sebuah perguruan tinggi untuk preservasi koleksi perpustakaan ialah meliputi kegiatan yang bersifat pencegahan dan penanggulangan kerusakan fisik dan atau pengalihmediaan isi dari sebuah format ke format lain. Standar ini bisa dijadikan acuan dalam pembuatan SOP yang akan dirancang guna mempermudah setiap proses kerja dan meminimalisir adanya kesalahan di dalam proses pelaksanaan pekerjaan. SOP juga berguna untuk menjadikan setiap pekerjaan bisa bekerja dengan efektif dan efisien. Hal ini dibuat untuk menghindari adanya tumpang tindih pelakasanaan tugas khususnya pada kegiatan pelestarian bahan perpustakaan dan menjamin proses kegiatan preservasi tetap berjalan sesuai dengan alurnya.

Berdasarkan pengamatan yang telah dilaksanakan perlu dibuat standard operating prosedure kegiatan pada preservasi koleksi khususnya pada perpustakaan UST. Hal ini disebabkan perpustakaan UST belum mempunyai peraturan khusus mengenai preservasi bahkan belum mempunyai SOP presevasi yang sudah disahkan oleh kepala perpustakaan yang sesuai dengan standar SOP serta berpedoman pada ketentuan perundangaundangan kebijkan kegiatan preservasi di perpustakaan UST. Berdasarkan latar belakang tersebut maka penulis bermaksud untuk membahas lebih lanjut mengenai permasalahan yang akan dipaparkan pada tulisan ini yang berjudul Penelusuran Informasi standar operating procedure Untuk Preservasi Koleksi (Studi Kasus di Perpustakaan Universitas Sarjanawiyata Tamansiswa Yogyakarta). 


\section{Tinjauan Pustaka}

\section{a. Literatur Review}

1) Pengertian Penelusuran Informasi

Penelusuran informasi adalah kegiatan menelusur kembali seluruh atau sebagian informasi yang pernah ditulis atau diterbitkan melalui sarana temu kembali informasi yang tersedia. Penelusuran yang baik adalah yang dilakukan secara sistematis, meliputi cara-cara bagaimana menggunakan kata kunci, subjek dokumen dan menggunakan logika. Tujuan dari penelusuran adalah untuk menemukan informasi yang cukup relevan dan berusaha untuk menghindari informasi yang tidak relevan, terlalu banyak informasi maupun terlalu sedikit informasi. Jadi penelusuran informasi diartikan sebagai suatu kegiatan untuk mencari atau menemukan kembali sebagian atau semua informasi yang dibutuhkan pemustaka yang telah disimpan dalam suatu sistem informasi atau dalam suatu pangkalan data, sehingga mendapatkan hasil secara cepat dan tepat/relevan

Penelusuran informasi juga diartikan sebagai kegiatan menelusur kembali seluruh atau sebagian informasi yang pernah ditulis atau diterbitkan melalui sarana temu kembali informasi yang tersedia.(Purwono 2008) Menurut Suwanto penelusuran informasi atau temu kembali infromasi adalah sebuah proses penemuan kembali informasi atau data yang telah disimpan dalam suatu sistem informasi atau suatu pengkalan data.(Suwanto and Sri Astuti 2002)

Penelusuran informasi menurut kamus kepustakawan Indonesia ialah sebuah kegiatan penemuan kembali akan literatur atau bahan pustaka dalam bidang tertentu dengan bantuan literatur sekunder, teknologi informasi atau sarana penelusuran lainya.(Lasa, HS 2017) Dapat disimpulkan bahwa penelusuran informasi ialah kegiatan mengetahui keberadaan sebuah bahan perpustakaan yang akan digunakan sebagai bentuk hasil dari informasi yang dibutuhkan sehingga mendapatkan informasi secara cepat dan tepat. 


\section{2) Standar Operating Procedure}

Secara umum standard operating procedure (SOP) atau standardization merupakan sebuah proses merencanakan, merumuskan, menetapkan, menerapkan, memberlakukan, memelihara dan mengawasi standar yang dilaksanakan secara tertib dan bekerja dengan semua pemangku kepentingan. Standarisasi ini mempunyai tujuan untuk meningkatkan jaminan mutu, efisiensi dan daya saing, serta untuk meningkatkan perlindungan kepada masyarakat, meningkatkan kepastian, kelancaran dan efisiensi pada sebuah kegiatan.(Lasa, HS 2017)

Operating ialah sebuah aktivitas yang mengambarkan alur kegiatan kerja yang baik secara rutin maupun tidak mempunyai keterikatan dengan kaidah-kaidah yang sudah ditentukan, bisa dipahami lebih dan aplikatif dalam bekerja. Secara aplikatif aktivitas-aktivitas kerja sesuai dengan kaidah atau standar yang diberlakukan. Procedure ialah sebuah langkah-langkah atau tahapan-tahapan yang berhubungan dengan proses dalam aktivitas bekerja, kegiatan prosedur perlu deskripsi yang jelas secara terperinci sehingga prosedur dapat berupa rincian tulisan ataupun gambar dengan tujuan lebih memudahkan akses informasi dan ketentuan yang dimaksud.(Joko Dwi Santoso 2014)

Secara khusus SOP dapat dipahami sebagai sekumpulan tulisan yang memuat langkah-langkah khusus dan spesifik yang menjelaskan tiap detail dari aktivitas untuk menyempurnakan tugas sesuai dengan regulasi pekerjaan. Langkah-langkah atau prosedur disusun sedemikian rupa dalam sebuah dokumen yang dapat diakses dam tentu saja dimiliki oleh setiap anggota. Dengan demikian dokumen tersebut berisi tata cara untuk menjalankan regulasi institusi yang bersangkutan, hal yang paling penting ditonjolkan dalam dokumen SOP ialah kejelasan langkah dari langkah satu, langkah dua dan seterusnya sehingga mengambarkan aktivitas yang dimaksud dalam tujuan institusi.(Joko Dwi Santoso 2014) Dari pengertian diatas sangat jelas terlihat bahwa SOP menjamin keberlangsungan hidup, atau regulasi pekerjaan sebuah institusi secara visioner kedepan, SOP juga menjadi batang tubuh atau sistem pokok yang harus dipatuhi dengan hal ini 
akan menjamin kesuksesan, keberhasilan dalam pekerjaan. Hal-hal Pokok dalam SOP harus memenuhi kriteria sebagai berikut:

a. Efisiensi, merupakan sebagai sebuah ketepatan yang berhubungan dengan kegiatan kerja, diharapkan menjadi lebih tepat sasaran tidak hanya cepat saja melainkan sesuai dengan tujuan atau target hasil yang ingin dicapai. (Joko Dwi Santoso 2014)

b. Konsistensi, merupakan hal-hal yang tetap, tidak berubah dan bisa dikalkulasikan untuk kemajuan suatu instansi, oleh karena itu semua yang terlibat didalamnya sangat membutuhkan kedisiplinan yang tinggi, tanpa kedisiplinan yang tinggi konsistensi tidak akan pernah tercapai dalam hal ini saling berhubungan dengan tujuan kemajuan instansi tersebut.

c. Minimalisasi kesalahan, Kegiatan ini dilakukan agar menjauhkan dari segala macam errors disetiap area yang sering mengalami kesalahan dalam pekerjaan.

d. Resolve (Penyelesain masalah), konflik antar relasi bisa saja terjadi bahkan seolah-olah tidak ada penengan yang bisa memecahkan konflik, namun apabila dikembalikan de dalam SOP yang sebelumnya yang disusun secara tepat maka tentu saja kedua belah pihak harus tunduk ada SOP tersebut, oleh karena itu semua konflik bisa diatasi dengan relatif mudah.

e. Tenaga kerja, langkah-langkah pasti dimana memuat segala tata cara untuk melindungi tiap-tiap sumber daya manusia dari potensi pertanggungjawaban dan berbagai persoalan personal, SOP memberi batas yang jelas secara sitematis agar kedua hal tersebut tidak bercampur aduk dan menimbulkan persoalan yang sudah diatasi.

f. Peta kerja, sebagai pola-pola dimana semua aktivitas yang sudah tertata rapi bisa dijalankan dalam pikiran masing-masing sebagai suatu kebiasaan yang pasti, dengan SOP pola kerja menjadi lebih fokus dan tidak melebar kemana-mana.

g. Batasan Pertahanan, SOP bisa diibaratkan sebagai benteng pertahanan yang kokoh karena secara prosudural segala aktivitas institusi ataupun perusahan sudah tertera dengan sangat jelas, dengan kata lain SOP memberikan kekuatan secara sistematik kepada institusi itu sendiri. 


\section{3) Preservasi}

Secara umum preservasi dapat diartikan sebagai pelestarian atau perawatan. Preservasi (preservation) hal ini mencakup semua hal seperti pertimbangan manajerial dan keuangan termasuk ketentuan penyimpanan dan akomodasi, sususan staf, kebijakan, teknik dan metode pelestarian bahan perpustakaan mengenai informasi yang terkandung didalamnya. Pelestarian berasal dari kata dasar "lestari" yang artinya tetap, tidak berubah, kekal, pelestarian merupakan proses, cara, perbuatan melestarikan, perlindungan dari kerusakan, dan pengawetan.("Kamus Besar Bahasa Indonesia (KBBI)" 1990)

Preservasi menurut Sulistiyo Basuki ialah sebuah kegiatan yang mencakup semua aspek usaha melestarikan bahan pustaka dan arsip, yang didalamnya termasuk kebijakan pengelolaan, keuangan, sumber daya manusia, metode dan teknik penyimpanannya.(Sulistiyo Basuki 1993) Menurut Sutarno N.S preservasi ialah suatu kegiatan yang dilakukan oleh kajian bidang ilmu perpustakaan dengan tujuan untuk memperpanjang umur bahan pustaka dan informasi yang ada didalam bahan perpustakaan tersebut.(Lasa, HS, 2009) Menurut Lasa. HS preservasi yaitu semua unsur kegiatan pengelolaan, keuangan, penyimpanan, alat bantu, ketenagakerjaan bahan pustaka, arsip maupun informasi yang terkandung didalamnya.(Lasa, HS 2009)

Berdasarkan penjelasan diatas dapat ditarik kesimpulan bahwa preservasi (preservation) merupakan sebuah kegiatan yang mencakup aspek untuk melestarikan dan memperpanjang usia dari bahan perpustakaan maupun arsip, saling berkaitan dengan perlindungan dan perbaikan atas bahan pustaka tersebut untuk mengurangi kerusakan bahan pustaka dari ancaman kerusakan.

Tujuan preservasi atau pelestarian tidak terlepas dari tujuan kebijakan pelestarian dan kaitannya dengan bahan perpustakaan. Menurut Martoatmojo tujuan preservasi ialah :

a) Menyelamatkan nilai informasi dokumen

b) Menyelamatkan bentuk fisik dokumen

c) Memperhemat kekurangan ruang 
d) Mempercepat perolehan informasi, seperti dokumen yang tersimpan dalam CD (compact disk) sangat mudah untuk diakses secara dekat maupun jauh.(Martoadmojo Karmidi 2010)

Sedangkan menurut Sulistiyo Basuki tujuan pelestarian dan arsip adalah melestarikan kandungan informasi yang tercantum didalam dokumen dan arsip dengan alih media atau bentuk menggunakan media lain atau melestarikan bentuk aslinya selengkap mungkin untuk dapat digunakan secara optimal.(Sulistiyo Basuki 1993) Dengan adanya kegiatan pelesatarian yang baik, diharapkan bahan perpustakaan dapat berumur lebih panjang, sehingga perpustakaan tidak perlu membeli koleksi yang sama.

\section{b. Penelitian Relevan}

Penelitian yang berhubungan dengan Penelusuran Informasi Standard Operating Procedure untuk preservasi koleksi merupakan sebuah kajian yang telah dilakukan oleh peneliti terdahulu, akan tetapi peneliti berkeyakinan bahwa penelitian ini belum pernah dilakukan di UPT Perpustakaan Universitas Sarjaniwiyata Tamansiswa Yogyakarta. dalam penelusuran yang telah dilakukan berkaitan dengan Standard Operating Procedure untuk preservasi koleksi, yang akan dijadikan kajian pustaka dalam penelitian ini. Ketiga penelitian tersebut dilakukan oleh:

Pertama jurnal oleh Okti Arzen Putra dan Elva Rahma, tahun 2018, dengan judul pembuatan standard operational procedure (SOP) layanan sirkulasi di perpustakaan SMA Pertiwi 1 Padang, tujuan penelitian ini ialah untuk mengambarkan persiapan dan pembangunan SOP layanan sirkulasi di perpustakaan SMA Pertiwi 1 Padang, metode yang digunakan kualitatif deskriptif, dengan menggunakan teknik pengumpulan data observasi dan wawancara. Hasil penelitian menyimpulkan SOP pada layanan sirkulasi dilakukan dengan cara mengetahui kebutuhan, mengevaluasi kerja dengan cara pembuatan SOP layanan sirkulasi.(Okti Arzen Putra and Elva Rahma 2018) Hal yang membedakan penelitian ini dengan tulisan peneliti ialah peneliti lebih membahas mengenai penelusuran informasi SOP khusus bagian preservasi koleksi. 
Kedua tesis oleh Miftahul Manan yang berjudul "Evaluasi kebijakan alih media pada bagian koleksi langka di Badan Perpustakaan dan Arsip Daerah Provinsi Daerah Istimewah Yogyakarta”, yang bertujuan untuk menganalisis kebijakan alih media pada koleksi langka dan membandingkan kebijakan alih media yang ada sesuai dengan prosedur SOP. Metode yang digunakan deskriptif-analitis. Hasil penelitian menyimpulkan bahwa proses kegiatan alih media koleksi langka yang berdasarkan pada kebijakan tertulis pada SOP harus terlebih dahulu memproses serta pengumpulan bahan pustaka kemudian baru melakukan kegiatan pengolahan.

Hal ini meliputi kegiatan presrvasi bahan perpustakaan yang akan dialih mediakan terdiri dari koleksi interen lingkungan perpustakaan. (Miftahul Manan 2015).

Ketiga skripsi oleh Endah Dwi Susanti dengan judul "Preservasi Koleksi langka di Perpustakaan Universitas Sanata Dharma (sebuah Kajian Alih Media). Tujuan penelitian untuk mengetahui kebijakan serta strategi proses alih media koleksi langka, mendeskripsikan proses kegiatan alih media cetak ke digital. Metoda yang digunakan kualitatif deskriptif. Hasil penelitian menyimpulkan kebijakan mengenai kegiatan pengalimedian koleksi sudah di atur dan diterapkan, kebijakan tersebut dituliskan pada Renstra Perpustakaan. Kegiatan alih media di Perpustakaan Sanata Dharma telah tercapai dengan proses yang telah ditentukan.(Endah Dwi Susanti 2018)

Dari beberapa hasil temuan related work yang telah dipaparkan diatas mempunyai kesamaan yaitu sama-sama membahas mengenai preservasi koleksi dalam ketentuan SOP. Sedangkan perbedaannya dengan penelitian yang akan peneliti lakukan ialah membahas penelusuran informasi standard operating prosedure untuk preservasi koleksi yang berpedoman pada standar operasional prosedur (SOP) pada koleksi yang berstandarkan pada hukum.

\section{Metode}

Desain pada penelitian ini menggunakan penelitian kualitatif dengan pendekatan studi literatur. Hal ini dilakukan untuk memperoleh gambaran yang lebih jelas mengenai penelusuran informasi Standard Operating Pro- 
cedure untuk preservasi koleksi di UPT Perpustakaan Sarjanawiyata Tamansiswa Yogyakarta. Objek penelitian yang akan dilakukan ialah bagian bidang pelestarian bahan perpustakaan, koleksi tendon, fokus pada penelitian ini ialah kriteria pada penelusuran informasi yang berpedoman pada Standard Operating Procedure koleksi.

Sasaran utama penelitian adalah informan yang bertindak sebagai penentu dan pembuat pedoman standar operasional prosedur preservasi sampai pada pelaksana teknis dilapangan, teknik penentuan informan dalam penelitian ini menggunakan teknik Snowball Sampling dengan penarikan sampel berdasarkan rekomendasi informan utama untuk mengetahui informan selanjutnya yang akan dijadikan sasaran sampel selanjutnya, dan sampai seterusnya sampai pada kejenuhan jawaban.(Adlin Alfathi 2008).

Teknik pengumpulan data berupa wawancara, observasi, dan studi kepustakaan setelah data didapatkan kemudian langkah selanjutnya melakukan validitas data, analisis data dengan rincian reduksi data, penyajian data dan penarikan kesimpulan.

\section{Hasil dan Pembahasan}

\section{Kebijakan Pengembangan Koleksi Berdasarkan Standar Perundang- Undangan Preservasi Koleksi}

Kebijakan pengembangan koleksi adalah suatu kebijakan yang mempunyai perencanaan dokumen yang perpustakaan di perpustakaan agar dapat memberikan informasi yang sesuai dengan tugas yang diemban oleh organisasi pusatnya. Kebijakan pengembangan koleksi juga merupakan suatu kebijakan seleksi yang terdiri dari prosedur tertulis tentang seleksi koleksi, dalam penyeleksian koleksi harus mempunyai alat-alat seleksi yang digunakan sebagai metode perlu diikuti dalam menentukan materi atau bahan perpustakaan yang akan dibeli.

Dalam kegiatan kebijakan pengembagan koleksi hendaknya mencakup semua kegiatan dalam dalam perkembangan koleksi yang berindikasi baik untuk jangka waktu yang akan datang. Dalam kebijakan pengembangan 
koleksi bisa dihubungkan dengan kegiatan preservasi yang mempunyai kaitan sangat erat. hal ini dijelaskan oleh Bonita Bryan (1989) dalam collection policies and preservations yaitu every library collections is established for one more definite purpose. Collection development and management program organizes and direct the process of acquiring materials, integrating them into coherent collection, managing their growth and waitence and deselecting them whwn appropriate in cost-and user-beneficial way.

Menurut teori Evans ada beberapa kriteria dalam kebijakan pengembangan koleksi yaitu yang pertama dengan mengidentifikasi, seleksi, akusisi, persiapan, interprestasi, penggunaan dan yang terakhir penyebaran informasi. (Evans, G Edward and Saponaro 2005) Mengenai hal ini setelah informasi tersebar kepada masyarakat pengguna langkah yang harus dilakukan yaitu penangan terhadap dokumen karena kegiatan pengembangan koleksi berkesanambungan dengan kegiatan preservasi atau pelestarian koleksi, untuk menangani kegiatan preservasi koleksi dalam skala besar harus mempunyai pernyataan tujuan yang jelas. Kebijakan koleksi akan membantu dalam menentukan perioritas preservasi yang mengarah pada kepentingan koleksi menjadi sasaran guna mencapai tujuan lembaga institusi yang ada.

Berdasarkan hasil wawancara dengan salah seorang pustakawan, menyatakan UPT Perpustakaan Sarjanawiyata Tamansiswa Yogyakarta dalam menentukan kebijakan skala dalam perioritas kecil maupun besar dalam melaksanakan kegiatan preservasi koleksi tidak mempunyai suatu ketentuan atau peraturan yang baku baik itu dalam bentuk penyataan tertulis maupun tidak tentang skala perioritas koleksi yang akan di preservasi, akan tetapi sejauh ini menyatakan UPT Perpustakaan Sarjanawiyata Tamansiswa Yogyakarta sudah hampir mendekati pada pelaksanaan kegiatan preservasi, hal ini terlihat pada keadaan apabila koleksi rusak ulah tangan pemustaka dengan segera memperbaiki sesuai degan kerusakan pada koleksi tersebut tanpa memperhitungkan ketentuak kebijakan dalam teori preservasi, karena lebih memfokuskan pada keselamatan koleksi yang rusak.

Landasan hukum yang digunakan dalam pelaksanaan kegiatan preservasi adalah Undang-undang No.4 tahun 1990 tentang Serah Simpan 
karya cetak dan Karya Rekam yang pada kenyataannya semua jenis koleksi harus disimpan dan disebarluaskan informasinya, landasan hukum lainnya tertera pada fungsi pelestarian suatu perpustakaan diatur dan dilaksanakan untuk memenuhi pasal 32 UUD 1945. Untuk itu semua pokok budaya bangsa dalam bentuk koleksi perpustakaan harus dilestarikan.

Oleh karena itu, kewajiban penerbit atau pembuat karya cetak/karya rekam untuk menyerahkan produknya agar dapat dilestarikan dalam koleksi nasional. Ketentuan tentang serah simpan karya cetak dan karya rekam telah diatur dengan peraturan pemerintah nomor 70 tahun 1991.

Faktor kunci program kegiatan preservasi yang efektif meliputi beberapa kandungan seperti memperhatikan kandungan informasinya, kandungan alamiahnya, lingkungan yang mempengaruhi baik fisik dan alih medianya serta kemampuan sumber daya saing disamping adanya komitmen yang kuat mengenai program preservasi melalui para pengambil kebijakan (manajer) maupun staf yang bertanggung jawab.

\section{Standar Operating Procedure (SOP) Preservasi Koleksi Berdasarkan Dasar Hukum Perundang-Undangan}

Menurut Loudon mengemukakan bahwa standart operating procedure is formal rules for accomplishing tasks that have been developed to cope with expected situations, bahwa SOP sebuah aturan formal yang digunakan untuk menyelesaikan permasalahan yang berkembang sesuai dengan situasi yang diharapkan, namun dengan demikian penerapan SOP perpustakaan tergantung dengan ketentuan internal perpustakaannya dan juga dari segi isi SOP dari beberapa perpustakaan berbeda-beda yang sesuai dengan kondisi perpustakaannya.(Loudan, K.J and Loudan, J.P 2000)

Dengan adanya SOP dapat mencerminkan sistem organisasi dan prosedur kegiatan kerja pustakawan, SOP juga merupakan salah satu bentuk dari pedoman dan petunjuk sebuah perpustakaan yang berfungsi untuk memeberikan bimbingan dan pengarahan kerja, dengan hal ini ada beberapa landasan hukum yang mendukung dalam kegiatan preservasi koleksi di perpustakaan yang berkaitan dengan standar operasional prosedur yaitu: 
a. SOP pengendalian dokumen NO. SOP 001.002/ot 01 02/isn6, yang memuat tentang pokok-pokok pengendalian dokumen sebagai berikut :

1. Menetapkan jenis dokumen

2. Membuat dokumen

3. Mengesahkan isi dokumen

4. Memberi identitas dokumen

5. Menomori dokumen

6. Menerbitkan dan mendistribusikan dokumen

7. Revisi dokumen

8. Menerbit ulang dokumen

9. Menarik dan memusnahkan dokumen

10. Meninjau ulang dokumen

b. Undang-Undang Nomor 13 tahun 2018 tentang serah simpan karya cetak dan karya rekam, Undang-undang yang memuat tentang pokok-pokok ini ialah:

1. Penyerahan karya cetak dan karya rekam

2. Pengelolaan hasil serah simpan karya cetak dan karya rekam
a. Penerimaan
b. Pengadaan
c. Pencatatan
d. Pengolahan
e. Penyimpanan
f. Pendayagunaan
g. Pelestarian

3. Pendanaan

4. Peran serta masyarakat

5. Penghargaan

c. Peraturan Kepala Perpustakaan Nasional Nomor 16 Tahun 2014 tentang tata cara penyimpanan dan penggunaan koleksi khusus. Memuat hal-hal pokok seperti : 
1. Penyimpanan koleksi khusus
a. Ruang penyimpanan
b. Penyusunan koleksi
c. Penempatan koleksi
d. Kondisi tempat penyimpanan
a) Tindakan perbaikan buku rusak
b) Fumigasi
c) Alih Media
d) Penyiangan koleksi

2. Penggunaan koleksi khusus

a. Penggunaan koleksi dilakukan secara terbatas

b. Penggunaan koleksi khusus ditujukan untuk kepentingan penelitian dan pendidikan

c. Koleksi khusus hanya digunakan ditempat atau ruangan layanan khusus yang disediakan tidak disebarluaskan

d. Pemustaka yang ingin meminjam terlebih dahulu mengajukan surat izin

d. SNI 7330:2009 perpustakaan Perguruan Tinggi, Pelestarian materi perpustakaan meliputi kegiatan:

1. Bersifat pencegahan

2. Penanggulangan kerusakan fisik

3. Pengalihmediaan isi dari sebuah format ke format lain.

Perpustakaan Universitas Sarjanawiyata Tamansiswa Yogyakarta dalam proses pelaksanaan kegiatan presrvasi koleksi belum ada pelaksanaan kegiatan yang terstruktur mengenai preservasi koleksi, hal ini berkaitan dengan belum adanya ketentuan atau kebijakan tertulis maupun tidak tertulis tentang SOP presrvasi, dengan hal ini menyebabkan terhalangnya kegiatan perawatan bahan perpustakaan di perpustakaan UST, hal ini merupakan hasil wawancara penulis dengan salah sau pustakawan perpustakaan UST. 


\section{Kesimpulan}

Kebijakan preservasi pada sebuah perpustakaan perlu direalisasikan guna untuk lebih memberi tekanan pada peraturan yang diciptakan secara tertulis yang mengacu pada undang-undang No. 4 Tahun 1990, didalamnya menjelaskan serta mengakomodasi semua kepentingan bagi koleksi sesuai dengan peraturan kebijakan preservasi yang tertuang dalam SOP dan pengendalian dokumen yang sudah tertuang pada Undang-undang tertentu, seperti pada Undang-undang SOP pengendalian dokumen yang tertuang pada No SOP 001.002/ot 01 01/isn 6, Undang-Undang Nomor 13 tahun 2018 tentang serah simpan karya cetak dan karya rekam, Peraturan Kepala Perpustakaan Nasional Nomor 16 Tahun 2014 tentang tata cara penyimpanan dan penggunaan koleksi khusus serta SNI 7330:2009 perpustakaan Perguruan Tinggi,

Dengan hal ini akan memungkinkan perpustakaan Universitas Sarjanawiyata Tamansiswa Yogyakarta bisa melaksanakan kebijakan preservasi dalam penentuan skala prioritas yang seragam dan sama berdasarkan pada pedoman yang akan menjadi bahan acuan para pustakawan bahkan juga tindak tegas yang akan dipimpin oleh kepala perpustakaan di lingkungan perpustakaan UST.

\section{Daftar Pustaka}

Abdul Rahman Saleh. 1995. Manajemen Perpustakaan Perguruan Tinggi. Jakarta: Universitas Terbuka.

Adlin Alfathi. 2008. Sebuah Pengantar Untuk "Mencari-Ulang" Metode Penelitian Dalam Psikologi. Yogyakarta: Jalasutrs.

Bonita Bryan. 1989. "Collection Policies and Preservations." Emerald.

Endah Dwi Susanti. 2018. "Preservasi Koleksi Langka Di Perpustakaan Universitas Sanata Dharma (Sebuah Kajian Alih Media).” Yogyakarta: UIN Sunankalijaga Yogyakarta.

Evans, G Edward, and Saponaro. 2005. Library and Informations Center. London: Library Unlimited.

Hartono. 2015. Dasar Manajemen Perpustakaan Dari Masa Ke Masa. Yogyakarta: UIN Maliki Press. 
Joko Dwi Santoso. 2014. Lebih Memahami SPO Standard Operating Procedure. Surabaya: Kata Pena.

"Kamus Besar Bahasa Indonesia (KBBI)." 1990. In Kamus Istilah Perpustakaan, 13. Jakarta: Kanisius.

Lasa, HS. 2009. Preservasi Dan Konservasi. Yogyakarta: Gama Media. -_- 2017. Kamus Kepustakawanan Indonesia. Yogyakarta: Calpulis.

Loudan, K.J, and Loudan, J.P. 2000. Management Information System. Cambridge: Prentice Hall.

Martoadmojo Karmidi. 2010. Pelestarian Bahan Perpustakaan. Jakarta: Universitas Terbuka.

Miftahul Manan. 2015. "Evaluasi Kebijakan Alih Media Pada Bagian Koleksi Langka Di Badan Perpustakaan Dan Arsip Daerah Provinsi Daerah Istimewa Yogyakarta." Skripsi, Yogyakarta: UIN Sunankalijaga Yogyakarta. Okti Arzen Putra, and Elva Rahma. 2018. "Pembuatan Standar Operational Procedure (SOP) Layanan Sirkulasi Di Perpustakaan SMA Pertiwi Padang." Jurnal Ilmu Informasi Perpustakaan Dan Kearsipan 6 (2): $27-35$.

Purwono. 2008. "Strategi Penelususran Informasi Melalui Internet." presented at the Makalah Seminar Himpunan Mahasiswa Jurusan Ilmu Perpustakaan Fakultas Adab dan Humaniora Universitas Islam Negeri Jakarta, Jakarta.

Rahayu Ningsih. 2007. Pengelolaan Perpustakaan. Yogyakarta: Graha Ilmu. Sulistiyo Basuki. 1993. Pengantar Ilmu Perpustakaan. Jakarta: Gramedia Pustaka.

Suwanto, and Sri Astuti. 2002. "Berbagai Kemajuan Dalam Penelusuran Informasi Ilmiah.” presented at the Makalah Pertemuan Jaringan Informasi BKKBN Provinsi Jawa Tengah, Jawa Tengah.

Wijayanti Luki. 2004. Perpustakaan Perguruan Tinngi, Buku Pedoman. Jakarta: Direktorat Jendral Pendidikan Tinggi Depdiknas.

Yuyu Yulia. 2009. Materi Pokok Pengembangan Koleksi. Jakarta: Universitas Terbuka. 